\title{
Molecular Characterization and Classification of Phytoplasmas Associated with Canola Yellows and a New Phytoplasma Strain Associated with Dandelions
}

\author{
Keri Wang, Graduate Research Assistant, and Chuji Hiruki, University Professor Emeritus, Department of Agri- \\ cultural, Food \& Nutritional Science, University of Alberta, Edmonton, Alberta, Canada, T6G 2P5
}

\begin{abstract}
Wang, K., and Hiruki, C. 2001. Molecular characterization and classification of phytoplasmas associated with canola yellows and a new phytoplasma strain associated with dandelions. Plant Dis. 85:76-79.

DNA isolated from symptomatic canola (Brassica napus, Brassica rapa) and dandelion (Taraxacum officinale) was used to amplify $16 \mathrm{~S}$ ribosomal DNA fragments by polymerase chain reaction using two pairs of universal primers P1/P6 and R16F2n/R2. Restriction fragment length polymorphism (RFLP) analysis of the amplified DNA fragments using endonucleases AluI, HhaI, HpaII, MseI, RsaI, and Sau3AI revealed two distinct types of phytoplasmas in canola with similar symptoms. One had the same RFLP profiles as the phytoplasmas in subgroup 16SrI-A, whereas the other one had RFLP profiles similar to those of phytoplasmas in subgroup 16SrI-B. Phytoplasmas were detected in symptomatic dandelion plants that were collected from canola and alfalfa fields where severe alfalfa witches'-broom occurred. Comparative studies indicated that two different phytoplasmas were associated with the dandelion plants. One was identified as a member of subgroup 16SrI-A, whereas another one was classified as a member of a distinct subgroup in the aster yellows group on the basis of the unique RFLP patterns.
\end{abstract}

Phytoplasmas causing diseases of the Brassica family have been reported in cabbage (3), sprouting broccoli, turnip, kale, and wild radish (22). Green petal of oilseed was first reported as a nonparasitic disorder by Schmidt in 1955. Later, the causal agent was believed to be one of the yellows type viruses that caused clover dwarf disease (13). Canola yellows (CanY), with symptoms similar to those of green petal of oilseed, have been observed in Alberta, Canada, since the 1980s and were considered to be caused by phytoplasmas on the basis of some shared teratological features with aster yellows disease (27).

Phytoplasmas, a group of obligatory parasites, are associated with severe diseases of a few hundred species important in agriculture, horticulture, and forestry (23). The introduction of the polymerase chain reaction (PCR) to analyze highly conserved genes has greatly improved the detection and identification of a broad range of phytoplasmas $(7,11,19,25)$. Restriction fragment length polymorphism (RFLP) and sequence analyses of PCRamplified 16S ribosomal RNA genes, the $16 / 23 \mathrm{~S}$ spacer region, and $16 \mathrm{~S}$ ribosomal protein genes have established a phyloge-

Corresponding author: C. Hiruki

E-mail: chiruki@afhe.ualberta.ca

Accepted for publication 28 September 2000.

Publication no. D-2000-1109-02R

(c) 2001 The American Phytopathological Society netic tree of phytoplasmas. Twenty major phylogenetic groups have been classified on the basis of molecular data derived from highly conserved genes (26).

In this study, PCR and RFLP analyses of employed to detect and identify the phytoplasmas associated with canola and dandelion by comparison with known strains of phytoplasmas. This study has revealed at least two different subgroups of phytoplasmas associated with each disease and their relationships to aster yellows phytoplasmas. In addition, it has identified a phytoplasma associated with dandelion as the member of a new subgroup.

\section{MATERIALS AND METHODS}

Plant samples and reference phytoplasma strains. Canola plants showing yellowing, green petal, and malformation of floral parts (CanY) were collected from a canola field in central Alberta. Diseased dandelion plants with symptoms of yellows (DanY) were sampled in the peripheral area of a canola field and in an alfalfa field in northern Alberta where samples of alfalfa witches'-broom (AWB) were collected. The reference phytoplasma strains used in this study included aster yellows (AY27), potato witches'-broom (PWB), and clover proliferation $(\mathrm{CP})$ which were previously collected in Alberta and maintained in periwinkle (Catharanthus roseus (L.) Don) in a greenhouse.

DNA extraction. Total nucleic acids were extracted from approximately $1 \mathrm{~g}$ of freshly cut midrib tissues or green petals of diseased samples as described previously the highly conserved $16 \mathrm{~S}$ rRNA gene were
(29). The asymptomatic canola and dandelion plants were tested for absence of phytoplasmas and used as healthy controls. The final pellets were dissolved in $50 \mu \mathrm{l}$ of TE (10 mM Tris, pH 8.0; 1 mM EDTA) buffer and diluted to a final concentration of approximately $20 \mathrm{ng}$ of nucleic acid per microliter with sterile deionized water.

Primer pairs and PCR amplification. The universal primers P1/P6 (8), which were designed on the basis of the $16 \mathrm{~S}$ rDNA sequence of Mollicutes, were employed to amplify an approximately $1,500-$ bp DNA fragment and were used in PCR assays for detection of various phytoplasmas. To detect potential mixed infections and to increase the sensitivity of PCR, the universal primers $R 16 \mathrm{~F} 2 \mathrm{n} / \mathrm{R} 2$, which were designed to amplify the partial $16 \mathrm{~S}$ rDNA fragment from most phytoplasmas (10), were used for nested PCR. The oligonucleotide sequence of these primers and base locations are P1, 5'-AAG AGT TTG ATC CTG GCT CAG GAT T-3' (6-30); P6, 5'-CGG TAG GGA TAC CTT GTT ACG ACT TA-3' (1491-1516); F16F2n, 5'-GAA ACG ACT GCT AAG ACT GG3' (149-168); and R16R2, 5'-TGA CGG GCG GTG TGT ACA AAC CCC G-3' (1373-1397).

For direct PCR, total nucleic acids extracted from healthy or diseased plant tissues were used as templates for PCR amplifications as described previously (29), with $200 \mu \mathrm{M}$ of each deoxynucleoside triphosphate (dNTP), $0.5 \mu \mathrm{M}$ of each primer, $1 \mathrm{U}$ of Taq DNA polymerase (Perkin-Elmer, Branchbury, NJ), and $40 \mathrm{ng}$ of template DNA in a $40 \mu \mathrm{l}$ reaction volume. Thirty-five PCR cycles were conducted in a DNA thermal cycler 2400 (Perkin-Elmer Cetus, Norwalk, CT) using the following conditions: denaturation at $94^{\circ} \mathrm{C}$ for $1 \mathrm{~min}$, annealing at $55^{\circ} \mathrm{C}$ for 1 min, and extension at $72^{\circ} \mathrm{C}$ for $2 \mathrm{~min}$. The final extension step was $10 \mathrm{~min}$ at $72^{\circ} \mathrm{C}$, and the reaction mixture was then held at $4^{\circ} \mathrm{C}$. Five microliters of the PCR products were analyzed by electrophoresis in a $1 \%$ agarose gel, and DNA bands were stained in ethidium bromide and visualized with a UV transilluminator.

In nested PCR, PCR products amplified by the universal primers P1/P6 were diluted 0 to 50 times in sterile deionized water based on the quantity of primary amplification and used as templates. The universal primers R16F2n/R2 were used and a subsequent series of 35 PCR cycles 
were performed under the conditions described above.

RFLP analysis of PCR-amplified DNA. To detect the potential mixed infections of phytoplasmas, the $16 \mathrm{~S}$ rDNA sequences $(1.2 \mathrm{~kb})$ amplified by nested PCR using primers $\mathrm{R} 16 \mathrm{~F} 2 \mathrm{n} / \mathrm{R} 2$ were analyzed by restriction endonuclease digestion. Five microliters of each PCR product were digested individually with each of the restriction endonucleases AluI, HhaI, HpaII, MseI, RsaI, and Sau3AI according to the manufacturer's instructions (GIBCO/BRL, Gaithersburg, MD). The restriction products were resolved on a vertical 5\% polyacrylamide gel, followed by staining in ethidium bromide. The DNA bands were then visualized using a UV transilluminator. The molecular weights of the fragments were determined by comparison with a 1-kb DNA ladder (BRL-life Technologies, Egenstein, Germany). The RFLP patterns of canola yellows and dandelion yellows phytoplasma DNA were compared with those of amplified DNA from the reference strains and previously published data $(1,4,19,25)$. The classification of subgroups was carried out by comparison with the data published by Gundersen $(11,12)$.

\section{RESULTS}

Detection of phytoplasmas in diseased canola and dandelion plants. With two universal primer pairs P1/P6 and R16F2n/R2, target DNA fragments of approximately $1.5 \mathrm{~kb}$ and $1.2 \mathrm{~kb}$ were amplified, respectively, by direct PCR from total nucleic acid samples extracted from diseased canola, dandelion, and alfalfa plants (data not shown). Weak bands were produced from the dandelion samples with both primer pairs, indicating low titers of phytoplasmas in the diseased dandelion

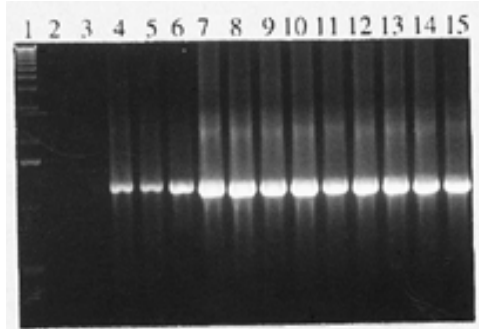

Fig. 1. Nested polymerase chain reaction amplification of 16S rDNA fragments from nucleic acids extracted from diseased and healthy canola, dandelion plants or AY27, alfalfa witches'-broom (AWB), clover proliferation (CP), and potato witches'-broom (PWB) phytoplasmas with primers P1/P6 followed by primers R16F2n/R2. Lane 1, 1 kb DNA marker; lanes 2 and 3, healthy canola and dandelion; lanes 4 and 5, diseased dandelion samples collected from the alfalfa field (DanY 99-1, DanY 99-2); lanes 6 and 7, diseased dandelion samples collected from the canola field (DanY1, DanY2); lanes 8 to 11, diseased canola samples (CanY1-4); lanes 12 to 15 , AY27, AWB, CP, and PWB, respectively. plants. Amplification of all reference phytoplasma strains that were maintained in periwinkle resulted in PCR products of approximately the same size as those from diseased canola and dandelion samples. No DNA band was observed when samples containing only DNA from healthy plants were examined. Nested PCR assays with the primer pair P1/P6 followed by the primer pair R16F2n/R2 yielded approximately $1.2-\mathrm{kb}$ DNA fragments with strong bands from all diseased samples and reference phytoplasma strains, but not from healthy plant samples (Fig. 1).

RFLP analyses of phytoplasma 16S rDNA sequences and identification of phytoplasmas. In the RFLP analyses of phytoplasma DNA from diseased canola and dandelion plants, nested PCR products with primers $R 16 F 2 n / R 2$ were used, since nested PCR is a highly sensitive way to detect mixed infections. All four canola yellows phytoplasma isolates produced identical RFLP patterns when restriction enzymes AluI, HpaII, RsaI, and Sau3AI were used to analyze the partial $16 \mathrm{~S}$ rDNA (Fig. 2). Two different RFLP profiles, however, were detected in four CanY phytoplasma isolates with the restriction endonuclease HhaI and MseI. Isolates CanY3 and CanY4 shared the identical RFLP patterns with AY27, which indicates that they are members of subgroup 16SrIA. For phytoplasma isolates CanY1 and CanY2, two fragments (approximately 150 and $160 \mathrm{bp}$ ), instead of one fragment (approximately $310 \mathrm{bp}$ ), were detected with $H h a \mathrm{I}$ restriction enzyme analysis. The MseI RFLP patterns of CanY1 and CanY2 isolates were also different from those of CanY3 and CanY4. Compared with previously published data $(12,19)$, CanY1 and CanY2 phytoplasma isolates were identified as members of subgroup 16SrI-B. The results indicate that phytoplasmas associated with canola yellows in Alberta belong to subgroups 16SrI-A and 16SrI-B.

RFLP analyses of phytoplasma $16 \mathrm{~S}$ rDNA fragments amplified by nested PCR from four diseased dandelion plants indicate that two different phytoplasma strains are associated with dandelion yellows (Fig. 2). Restriction profiles of two phytoplasma isolates (DanY1, DanY2) collected from the canola field were identical with those of one isolate (DanY99-2) collected from the alfalfa field and AY27 phytoplasma, indicating that these phytoplasma isolates are closely related to each other and belong to subgroup 16SrI-A. Phytoplasma isolate DanY99-1 collected from the alfalfa field, however, showed restriction profiles different from those of all phytoplasmas that were included in this study and those of previously reported data $(12,19,24)$. When restriction endonuclease $A l u \mathrm{I}$ was used to digest the 16S rDNA fragment amplified by nested PCR, DanY99-1 did not produce a band approximately $370 \mathrm{bp}$ in length, whereas a band at approximately $420 \mathrm{bp}$ was more intensively stained than the corresponding bands produced by AY27, CanY, and other DanY isolates. Apparently, the band of approximately $420 \mathrm{bp}$ represented two DNA fragments that comigrated, based on the calculation of total length of the $16 \mathrm{~S}$ rDNA fragment. In addition, restriction patterns of DanY99-1 with the other five restriction enzymes also were slightly different from those of AY27, CanY, and other DanY isolates. The 16S rDNA fragment amplified from DanY99-1 appeared slightly larger than those amplified from the other AY group phytoplasmas used in this study. The results suggest that this phytoplasma isolate should be assigned to a new subgroup in the AY group.

The alfalfa witches'-broom sample shared identical RFLP profiles with the reference phytoplasma strains $\mathrm{CP}$ and PWB with all restriction endonucleases used in this study, indicating that they are in the same group as reported previously $(7,17)$.

\section{DISCUSSION}

In this study, we analyzed canola yellows and dandelion yellows in Alberta. Although canola yellows and dandelion yellows exhibit very similar symptoms, RFLP analyses of $16 \mathrm{~S}$ rDNA sequences amplified from canola yellows and dandelion yellows phytoplasma revealed that at least two genetically distinct phytoplasmas were associated with each of these diseases. This suggests that canola and dandelion plants are susceptible to both types of phytoplasmas, which produce very similar symptoms. Previous studies have also indicated that different types of phytoplasmas are associated with the same host species and induce similar symptoms. For example, tomato big-bud diseases are associated with four different types of phytoplasmas from the AY, FBP (favabean phyllody), EY (elm yellows), and Xdisease groups in different geographical origins $(5,9,19,25)$. Similarly, grapevine yellows can be induced by phytoplasmas of the EY group or by members of the stolbur, AY, and X-disease groups (20).

Subgroup 16SrI-B has the largest number of members in the group 16SrI (26). Phytoplasmas associated with diseases of the Brassica family including cabbage (22, 28 ), broccoli, kale, turnip (22), and rapeseed $(4,15,28)$ have been reported in previous studies and identified as members of subgroup 16SrI-B. Phytoplasmas belonging to the subgroup 16SrI-B seem to be the most widespread in Europe and America $(19,28)$. The phytoplasma in subgroup $16 \mathrm{Sr}$ I-A has not been reported to be associated with Brassica sp. plants. We report, for the first time, that the phytoplasma in subgroup 16SrI-A, in addition to 16SrI-B, is associated with canola yellows disease in Alberta. Our recent studies (Wang and Hiruki, unpublished data) indicate that most phytoplasmas associated with yel- 
lows-type symptoms in Alberta belong to subgroup 16SrI-A or 16SrI-B with an approximately equal distribution.

The highly sensitive nested-PCR assay described by Lee et al. (18) provides the capability to detect phytoplasmas with a very low concentration in diseased plants and enables the detection of mixed infections by phytoplasmas. By use of this technique, many phytoplasma diseases were found to be associated with more than one type of phytoplasma $(2,16,18,21)$. Mixed infections may be more common in perennial plants than in annual plants, since long life spans provide vast opportunities to be inoculated by vectors infested with various phytoplasma pathogens. Nevertheless, nestedPCR used in this study was unable to detect a mixed infection, although two types of phytoplasmas were present in plants exhibiting symptoms of canola yellows and dandelion yellows. This might be due to an insufficient number of samples collected from the fields. A large number of field samples are being studied for mixed infections.

RFLP analysis of 16S rDNA showed that diseased dandelion plants collected from the canola field were associated with a homogeneous phytoplasma that is similar, or identical, with one type of canola yellows phytoplasma. Since dandelion roots can survive during winter, dandelion plants are capable of serving as a natural source of canola yellows phytoplasma. Aster yellows phytoplasmas are widespread worldwide (26). Recently, AY phytoplasmas associated with monarda (29) and parsley (14) have been reported in Alberta. Our recent studies (6; Wang and Hiruki, unpublished data) also indicated that many garden plants affected by yellows including strawflower, French marigold, California poppy, clarkia, and spinach also are infected with AY phytoplasmas in Alberta.

In this study, we showed that dandelion yellows phytoplasmas were distinct from AWB phytoplasma, although the diseased dandelion plants were collected in alfalfa fields where AWB was widespread. The results suggest that dandelion yellows and alfalfa witches'-broom phytoplasmas do not cross infect. For dandelion yellows, further investigation of phytoplasmainduced diseases on other crops or weeds in northern Alberta is needed to understand the transmission of DanY phytoplasma to other plants. CP and PWB phytoplasmas, closely related to AWB phytoplasma, are also common in this area $(8,17)$.

Phytoplasmas in the AY group exhibit great genetic diversity and have been divided into more than nine subgroups (26). An increasing number of new subgroups have been identified in the AY group (24). In this study, RFLP analysis of the $16 \mathrm{~S}$ rDNA fragment of dandelion yellows phytoplasmas and comparison of RFLP profiles with the previously published data $(12,19,24)$ indicate that dandelion yellows phytoplasma DanY 99-1 (Fig. 2) is affiliated with the AY group but clearly different from all members of the AY group reported thus far. Since the DNA fragment amplified from DanY 99-1 is slightly larger than those from AY27, CanY, and other DanY phytoplasmas, a small DNA fragment is probably inserted in the $16 \mathrm{~S}$ rDNA of DanY 99-1. Work is in progress to confirm this hypothesis.

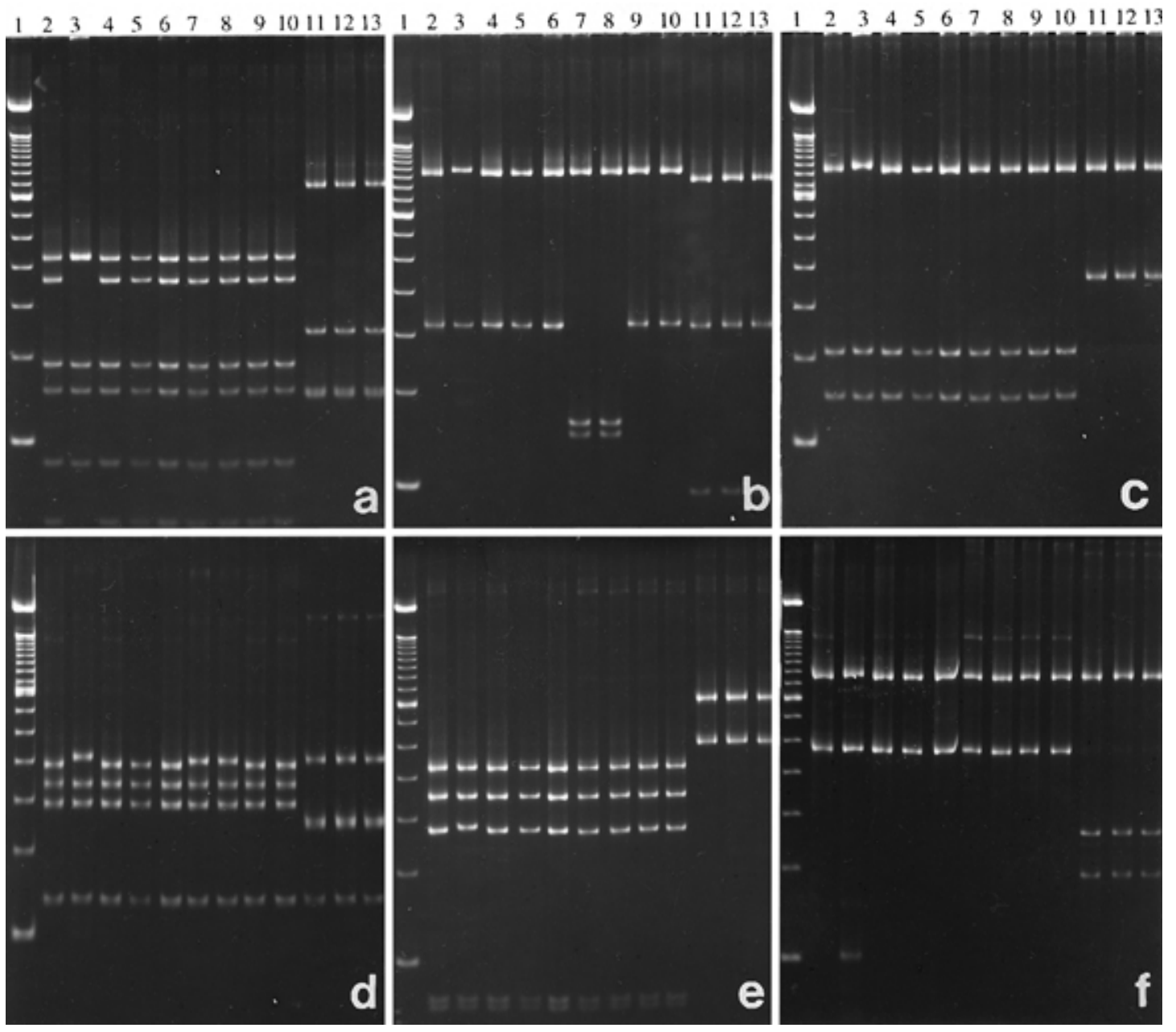

Fig. 2. Restriction fragment length polymorphisms of phytoplasma $16 \mathrm{~S}$ rDNA amplified by nested polymerase chain reaction with primers R16F2n/R2 and primers P1/P6. DNA products were digested with restriction enzymes and separated by electrophoresis through a $5 \%$ polyacrylamide gel. A, AluI, B, $H h a \mathrm{I}$, C, HpaII, D, MseI, E, RsaI, F, Sau3AI. Lane 1, 1 kb DNA marker; lane 2, AY27; lanes 3 and 4, diseased dandelion samples collected from the alfalfa field (DanY 99-1, DanY 99-2); lanes 5 and 6, diseased dandelion samples collected from the canola field (DanY1, DanY2); lines 7 to 10, diseased canola samples (CanY1-4); lanes 11 to 13, alfalfa witches'-broom, clover proliferation, and potato witches'-broom, respectively. 


\section{ACKNOWLEDGMENTS}

Research was supported by a grant (A3843) from the Natural Sciences and Engineering Research Council of Canada.

\section{LITERATURE CITED}

1. Ahrens, U., and Seemüller, E. 1992. Detection of DNA of plant pathogenic mycoplasmalike organisms by a polymerase chain reaction that amplifies a sequence of the 16S rRNA gene. Phytopathology 82:828-832.

2. Alma, A., Davis, R. E., Vibio, M., Danielli, A., Bosco, D., Arzone, A., and Bertaccini, A. 1996. Mixed infection of grapevines in northern Italy by phytoplasmas including $16 \mathrm{~S}$ rRNA RFLP subgroup 16SrI-B strains previously unreported in this host. Plant Dis. 80:418-421.

3. Bertaccini, A., Davis, R. E., and Lee, I.-M. 1990. Distinction among mycoplasmalike organisms (MLOs) in Gladiolus, Ranunculus, Brassica and Hydrangea through detection with nonradioactive cloned DNA probes. Phytopathol. Mediterr. 29:107-113.

4. Bertaccini, A., Vorácková, Z., Vibio, M., Fránová, J., Navrátil, M., Špak, J., and Nebesárová, J. 1998. Comparison of phytoplasmas infecting winter oilseed rape in the Czech Republic with Italian Brassica phytoplasmas and their relationship to the aster yellows group. Plant Pathol. 47:317-324.

5. Boudon-Padieu, E., Cousin, M. T., Daire, X., and Roux, J. 1996. Molecular and serological characterization of phytoplasma isolates inducing tomato stolbur symptoms in tomato. IOM Lett. 4:167-168.

6. Ceranic-Zagorac, P., and Hiruki, C. 1996. Comparative molecular studies on aster yellows phytoplasmas. Acta Hortic. 432:266276.

7. Deng, S., and Hiruki, C. 1990. Molecular cloning and detection of DNA of the mycoplasmalike organism associated with clover proliferation. Can. J. Plant Pathol. 12:383-388.

8. Deng, S., and Hiruki, C. 1991. Amplification of $16 \mathrm{~S}$ rRNA genes from culturable and nonculturable mollicutes. J. Microbiol. Methods 14:53-61.

9. Gibb, K. S., Persley, D. M., Schneider, B., and Thomas, J. E. 1996. Phytoplasmas associated with papaya diseases in Australia. Plant Dis. 80:174-178.

10. Gundersen, D. E., and Lee, I.-M. 1996. Ultrasensitive detection of phytoplasmas by nested-PCR assays using two universal primer pairs. Phytopathol. Mediterr. 35:144-151.

11. Gundersen, D. E., Lee, I.-M., Rehner, S. A., Davis, R. E., and Kingsbury, D. T. 1994. Phylogeny of mycoplasmalike organisms (phytoplasmas): A basis for their classification. J. Bacteriol. 176:5244-5254.

12. Gundersen, D. E., Lee, I.-M., Schaff, D. A., Harrison, N. A., Chang, C. J., Davis, R. E., and Kingsbury, D. T. 1996. Genomic diversity and differentiation among phytoplasma strains in 16S rRNA groups I (aster yellows and related phytoplasmas) and III (X-disease and related phytoplasmas). Int. J. Syst. Bacteriol. 46:64-75.

13. Horváth, J. 1969. Green petal: A new disease of rape in Hungary. Acta Phytopathol. Acad. Sci. Hung. 4:363-367.

14. Khadhair, A. H., Kawchuk, L. M., Raillon, R. C., and Botar, G. 1998. Detection and molecular characterization of an aster yellows phytoplasma in parsley. Can. J. Plant Pathol. 20:55-61.

15. Kuske, C. R., Kirkpatrick, B. C., and Seemüller, E. 1991. Differentiation of virescence MLOs using western aster yellows mycoplasma-like organism chromosomal DNA probes and restriction fragment length polymorphism analysis. J. Gen. Microbiol. 137:153-159.

16. Lee, I.-M., Bertaccini, A., Vibio, M., and Gundersen, D. E. 1995. Detection of multiple phytoplasmas in perennial fruit trees with decline symptoms in Italy. Phytopathology 85:728-735.

17. Lee, I.-M., Davis, R. E., and Hiruki, C. 1991. Genetic interrelatedness among clover proliferation mycoplasmalike organisms (MLOs) and other MLOs investigated by nucleic acid hybridization and restriction fragment length polymorphism analyses. Appl. Environ. Microbiol. 57:3565-3569.

18. Lee, I.-M., Gundersen, D. E., Hammond, R. W., and Davis, R. E. 1994. Use of mycoplasmalike organism (MLO) group-specific oligonucleotide primers for nested-PCR assays to detect mixed-MLO infections in a single host plant. Phytopathology 84:559-566.

19. Lee, I.-M., Hammond, R. W., Davis, R. E., and Gundersen, D. E. 1993. Universal amplification and analysis of pathogen 16S rDNA for classification and identification of mycoplasmalike organisms. Phytopathology 83: 834-842.

20. Marcone, C., Ragozzino, A., Credi, R., and Seemüller, E. 1996. Detection and characteri- zation of phytoplasmas infecting grapevine in southern Italy and their genetic relatedness to other grapevine yellows phytoplasmas. Phytopathol. Mediterr. 35:207-213.

21. Marcone, C., Ragozzino, A., Schneider, B., Lauer, U., Smart, C. D., and Seemüller, E. 1996. Genetic characterization and classification of two phytoplasmas associated with spartium witches'-broom disease. Plant Dis. 80:365-371.

22. Marcone, C., Ragozzino, A., and Seemüller, E. 1997. Detection and identification of phytoplasmas infecting vegetable, ornamental, and forage crops in southern Italy. J. Plant Pathol. 79:211-217.

23. McCoy, R. E., Caudwell, A., Chang, C. J., Chen, T. A., Chiykowski, L. N., Cousin, M. T., Dale, J. L., De Leeuw, G. T. N., Golino, D A., Hackett, K. J., Kirkpatrick, B. C., Marwitz, R., Petzold, H., Sinha, R. C., Sugiura, M., Whitecomb, R. F., Yang, I. L., Zhu, B. M., and Seemüller, E. 1989. Plant diseases associated with mycoplasmalike organisms. Pages 545-640 in: The Mycoplasmas. Vol. 5. R. F. Whitcomb and J. G. Tully, eds. Academic Press, San Diego.

24. Sawayanagi, T., Horikoshi, N., Kanehira, T., Shinohara, M., Bertaccini, A., Cousin, M.-T., Hiruki, C., and Namba, S. 1999. 'Candidatus phytoplasma japonicum', a new phytoplasma taxon associated with Japanese Hydrangea phyllody. Int. J. Syst. Bacteriol. 49:12751285 .

25. Schneider, B., Ahrens, U., Kirkpatrick, B. C., and Seemüller, E. 1993. Classification of plant-pathogenic mycoplasmalike organisms using restriction-site analysis of PCR amplified 16S rDNA. J. Gen. Microbiol 137:519-527.

26. Seemüller, E., Marcone, C., Lauer, U., Ragozzino, A., and Goschl, M. 1998. Current status of molecular classification of the phytoplasmas. J. Plant Pathol. 80:3-26.

27. Tewari, J. P., and Skorapad, W. P. 1981 Teratology of infection in Brassica campestris and Thlaspi arvense by a mollicute-like pathogen. (Abstr.) Can. J. Plant Pathol. 3:120.

28. Vibio, M., Bertaccini, A., Lee, I.-M., Davis, R. E., and Clark, M. F. 1996. Differentiation and classification of aster yellows and related European phytoplasmas. Phytopathol. Mediterr. 35:33-42.

29. Wang, K., Hiruki, C., and Chen, M. H. 1998 Identification of a phytoplasma causing yellows of Monarda. Plant Pathol. 47:103-106. 